\title{
ENGINEERING MATHEMATICS
}

MSC 49K35

DOI: $10.14529 /$ jcem200401

\section{OPTIMIZING FIRE-FIGHTING WATER SUPPLY SYSTEMS USING SPATIAL METRICS}

\author{
A. V. Kalach ${ }^{1}$, AVKalach@gmail.ru, \\ V. A. Rodin ${ }^{2}$, rodin_v@mail.ru, \\ S. V. Sinegubov ${ }^{2}$, sinusdvm@mail.ru \\ 1 Voronezh Institute of Russian Federal Penitentiary Service, Voronezh, Russian \\ Federation \\ ${ }^{2}$ Voronezh Institute of the Ministry of Internal Affairs of Russia, Voronezh, Russian \\ Federation
}

\begin{abstract}
The current trend in the construction of new urban areas involves the coordination of a comprehensive preliminary planning of all systems and networks of power supply, water supply, drainage complexes, laying of communication networks and other communication networks of construction objects with the layout of residential buildings. In the paper there is an optimization of the number and type of distribution of hydrants of external firefighting water supply and pumping stations using various metrics that measure distance. The optimization of the dependence of the type of hydrant water supply networks on pumping stations is considered, considering the real practical tasks of providing fire-fighting water supply, taking into account the size, location and shape of modern buildings. The analysis of maps and standards revealed that the concept of distance implies only distance in a straight line that does not correspond to the modern layout of the development of subdistricts and significantly complicates the ability of firefighters to work. In the first part of the work, we present a mathematical model that optimizes both the number and the location of the set of hydrants that fully serve a given development area. The optimization algorithm uses a metric different from Euclidean distance. At the same time, it is assumed that the developed models are applicable for various types of development of subdistricts (line building, regular building, cluster housing, sporadic building, etc.). In the second part of the paper, we optimize the number of placement of pumping stations and the type of pipeline network connecting the fire-fighting water supply and pumping stations. To this end, we use the computer determination of the coordinates of the Torricelli - Steiner point implemented for an arbitrary set of consumer points and various spatial metrics.
\end{abstract}

Keywords: location algorithm; fire hydrant; fire-fighting water supply; modelling; spatial metrics; Torricelli - Steiner points.

\section{Introduction}

Protection of the population, material wealth and territories from emergency situations (including fires) is an integral part of the work of the state. Fighting fires is currently showing positive trend. The current trend in the construction of new urban areas involves the comprehensive planning of all social, communal, cultural and commercial construction objects to be coordinated with the layout of the placement of residential buildings and service communications [1-5]. 
In contrast to [1-5], in this paper, optimization algorithms for the placement of hydrants of external fire-fighting water supply and pumping stations are constructed using spatial non-Euclidean distances. The problems solved in the paper are characterized by geometrical and spatial nature. Some statements were announced in the paper [6]. The work [7] considers the mathematical description of the processes during the passage of fluid through pipelines with given parameters under conditions of restrictions.

\section{Placement of Fire Hydrants}

\subsection{Analysis of Practical Situation}

The study of existing maps in the networks (Fig. 1a, 1b) showed a complete lack of regularity in determining the required number of hydrants as well as a justification for their layout. In certain areas, there is a clear excess of the number of hydrants (Fig. 1a), and, in some areas, we can identify parts of buildings located at a distance which is more than $200 \mathrm{~m}$ from all hydrants (Fig. 1b), that is a regulatory violation takes place.
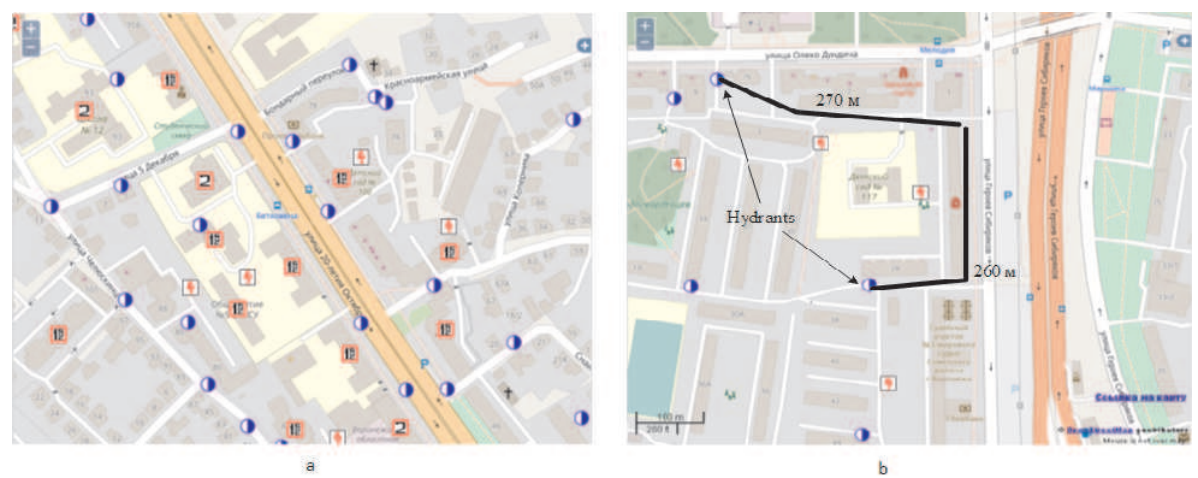

Fig. 1. Network map for location of an excessive (a) and insufficient (b) number of fire hydrants

A survey by practitioners showed that insufficient attention was paid to the placement of fire hydrants. During construction, hydrants are placed at the distance of $200 \mathrm{~m}$ from buildings without taking into account their size, shape and number of floors and this distance is considered to be sufficient. Practitioners are interested in the method of calculating the action radius of hydrants under various conditions, which is absent in regulatory documents. The location of two hydrants on adjacent distribution lines is determined [4] by the equation

$$
(2 r)^{2}=a^{2}+\left(l_{r}\right)^{2}
$$

where $a$ is a distance between the lines; $r$ is a radius of action of a hydrant; $l_{r}$ is a length of the fire-fighting line. Formula (1) has no practical focus and does not take into account the peculiarities of the architectural and construction planning of the area, the shape and size of buildings. In addition, formula (1) regulates significant distances between hydrants, which, as we show below, is not always justified and leads to an increase in the number of hydrants and ineffective use of equipment. In all recommendations and standards, the distance from the fire-fighting water supply to the extinguishing object is measured only by a straight line, that is, in terms of Euclidean distance. In fact, it presupposes the historically established idea of the insignificant size of buildings, low number of floors and the disunity of objects. 


\subsection{Application of Various Metrics}

Let $l_{p}^{N}, 0 \leqslant p \leqslant \infty$, be coordinate Banach spaces [8] with the norm $\|C\|_{l_{p}}=\left(\sum_{k=1}^{N}|c|^{p}\right)^{\frac{1}{p}}$ and $\|C\|_{l_{\infty}}=\max \left|c_{k}\right|$.

For $p=2$, we have $l_{2}$ with Euclidean distance, or along a straight line, where the distance is estimated as

$$
\rho_{e}\left(M_{1}, M_{2}\right)=\sqrt{\left|x_{1}-x_{2}\right|^{2}+\left|y_{1}-y_{2}\right|^{2}} .
$$

In the case of a metric in the space, some papers consider the so-called Manhattan distance (Fig. 2) determined by the formula

$$
\rho_{m}\left(M_{1}, M_{2}\right)=\left|x_{1}-x_{2}\right|^{2}+\left|y_{1}-y_{2}\right|^{2} .
$$

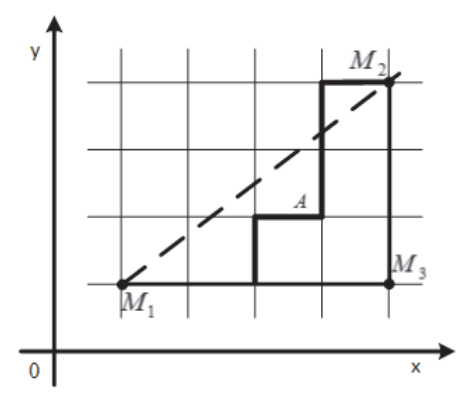

Fig. 2. Schematic explanation of Manhattan distance

Note that, in the metric of the space $l_{1}$, the distances from the point $M_{1}$ to the point $M_{2}$ calculated along both the broken line $M_{1}-M_{3}-M_{2}$ and the stepped line $M_{1}-A-M_{2}$ (Fig. 2) are equal. In this case, the line can be changed by shifting and increasing the links of the broken line up to the level $y=y_{2}$ and to the right to the vertical line $x=x_{2}$. This useful property allows to design the laying of connecting pipes, bypassing the rectangular foundations of buildings without increasing the length of the laying.

There is a possibility of various options of planning, for example, placing the segments of connections along the auxiliary streets between buildings (Fig. 6, 9).

\subsection{Model Based on Size, Shape, and Location of Buildings}

In this paragraph, we propose new algorithms and models of mathematical basis of the optimality of the number and location of hydrants of external fire-fighting water supply. Note that the distance when laying both creeping and vertical planes does not occur in a straight line (along the hypotenuse, the standard Euclidean distance), but it is forced to take into account the usual rectangular shape of the building. In this case, the distance is measured as the sum of the legs (or the metric of the coordinate space $l_{1}$ ), taking into account the building of streets in the form of a graph notebook (Fig. 2).

Consider one building (Fig. 3). In this case, it is necessary to change the length of the fire-fighting line, the distance between the extreme points $M_{1}$ and $M_{2}$ is calculated using the formula $\rho_{m}\left(M_{1}, M_{4}\right)=\left|x_{2}-x_{1}\right|^{2}+\left|y_{2}-y_{1}\right|^{2}$. This is a half of a rectangular building perimeter. 
When placing the fire-fighting water supply in the rectangle zone $D_{1}, D_{2}, D_{3}, D_{4}$, the condition under which all parts of the building are available for fire extinguishing has the form

$$
1,2 \cdot\left[\rho_{m}\left(M_{1}, M_{4}\right)+2 d\right] \leqslant R .
$$

Here 1,2 is the coefficient used in practice, taking into account the tortuosity of a fire hose. The existing standard $R=200 \mathrm{~m}$ can be changed by agreement.

Condition (4) leads to the following requirement on the size of the fire-fighting water supply service area:

$$
d=\frac{R / 1,2-\rho_{m}\left(M_{1}, M_{2}\right)}{2}
$$

Condition (5) defines a new clear rule for the location of hydrants for large rectangular objects.

Namely, if $d \leqslant 0$ (a large building, stadium, hangar, factory workshops, etc.), then hydrants should be located in close proximity, or even inside such buildings. Hereinafter, we assume that $d>0$ (Fig. 3).

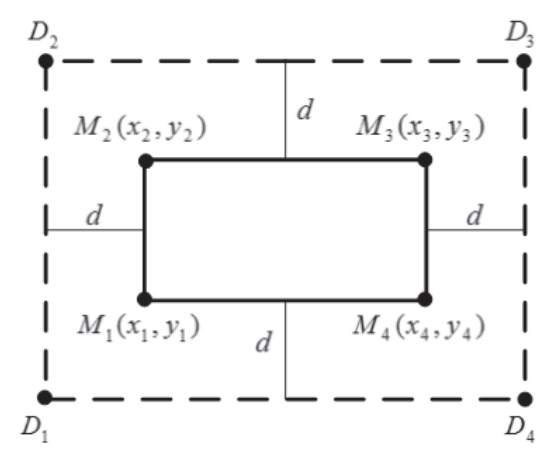

Fig. 3. Graphic explanation of the proposed rule for the location of hydrants for large objects

According to construction requirements, buildings can be located at a distance of 20 $25 \mathrm{~m}$ from each other. Fire passages between buildings are equal to $9 \mathrm{~m}$. The dimensions of the building can be several times larger than these distances and comparable with the requirement to locate hydrants at a distance not exceeding $R=200 \mathrm{~m}$. Therefore, the coverage model should change the size of the affected zones taking into account the size of buildings. Fig. 1 presents a spontaneous example in some areas.

A complex building can be considered as several buildings standing side by side (Fig. 4).
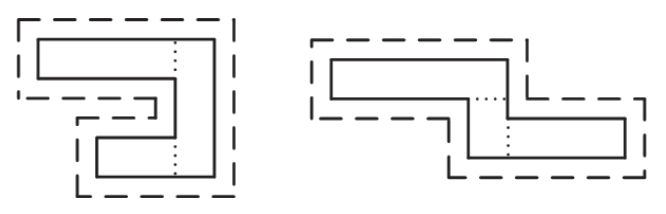

Fig. 4. Graphic designation of the service area of several adjacent buildings 


\subsection{Optimal Algorithm of Hydrant Placement}

For each building $I$, using formula (5), we calculate the parameter $d_{I}$. If $d_{I} \leqslant 0$ (a large building), then all the necessary hydrants (we optimize the number below) must be located in the immediate vicinity or inside the building.

If $d_{I}>0$, then the algorithm for determining the optimal location of hydrants is as follows: when planning the location of buildings around each building, we construct a neighborhood in the form of a rectangular area with dimensions determined by formula (5).

Therefore, under the condition $d_{I}>0$, each coverage area has its own size depending on the size of the building. In this case, the natural optimization of the number of firefighting water supply that can serve several buildings standing nearby is the strategy of their location in a possible intersection zone (Figs. 5a, 5b).
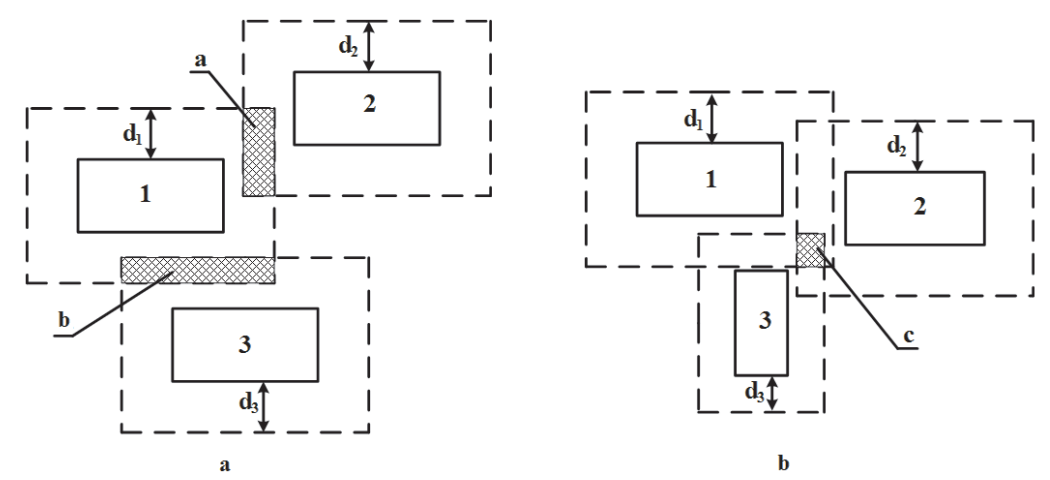

Fig. 5. Example of a fire water supply location for several buildings

It is possible to check the conditions for the appearance and the place of intersection of zones mathematically (or graphically, on the layout map).

For the zone $a$ (Fig. 5a), at the intersection of two feasible zones, these conditions are

$$
\begin{aligned}
& \max \left(d_{1}, d_{2}\right)<\left|x_{2}-x_{1}^{\prime}\right|<d_{1}+d_{2} \\
& \max \left(d_{1}, d_{2}\right)<\left|y_{2}-y_{2}^{\prime}\right|<d_{1}+d_{2} .
\end{aligned}
$$

For the zone $b$ (Fig. 5b), at the intersection of two feasible zones, these conditions are

$$
\begin{aligned}
& \max \left(d_{1}, d_{3}\right)<\left|x_{2}-x_{1}^{\prime \prime}\right|<d_{1}+d_{3} \\
& \max \left(d_{1}, d_{3}\right)<\left|y_{2}-y_{2}^{\prime \prime}\right|<d_{1}+d_{3} .
\end{aligned}
$$

If the right side of the inequalities is not fulfilled in any line, then the zones do not intersect, if the left side is not fulfilled in any line, then the zone can be reduced or located in the close proximity of the building.

For three buildings (the zone $c$ (Fig. 5b)), the conditions for the existence of the intersection zone of the three regions is that all four two-sided inequalities (6) and (7) are fulfilled simultaneously.

Here (see Fig. 3) the coordinates $\left(x_{k}, y_{k}\right)$ and the parameter $d_{1}$ belong to the left rectangle, the coordinates $\left(x_{k}^{\prime}, y_{k}^{\prime}\right)$ and the parameter $d_{2}$ belong to the upper rectangle, the coordinates $\left(x_{k}^{\prime \prime}, y_{k}^{\prime \prime}\right)$ and the parameter $d_{3}$ belong to the right rectangle. If the righthand side of the inequalities is not fulfilled, there is no common intersection zone of the 
three intervals; if the left-hand sides of the inequalities are not fulfilled, the intersection zone captures part of the third building and hydrants can be located in the close proximity of the building or in the building itself. Inequalities and conditions are easily programmed, that allows to create a PC program for the placement of fire-fighting water supply.

We suggest placing hydrants in shaded rectangles in the corners of this rectangular area. This arrangement is also optimal for building maintenance.

Therefore, we propose both a new graphical algorithm for the optimal placement of hydrants for external fire extinguishing and a mathematical model for optimizing the number of these hydrants. The dimensions, shapes and locations of modern buildings do not allow modelling optimization problems in radial shapes (in the form of circles of influence). Namely, the requirements [4] are written in these terms, which have survived since then the small size of buildings allowed formulating rules in the form of zones, i.e. circles. In addition, the graphically compact arrangement of hydrants proposed in the paper allow to save the number of distribution lines, as well as the number of fire hoses and other equipment during routing. For the given coordinates of the corners of the projected buildings, their number of storeys, the status of belonging, the process of constructing zones for placement and the number of hydrants can be automated and implemented in the form of computer graphics.

In modern rules regulating the number of hydrants, there is no pattern that takes into account the status of the building and the location of the hydrants relative to buildings. The algorithms mentioned in the paragraph show that by placing hydrants in the intersection zone of the constructed areas, their number can be reduced by more than three. Therefore, for three buildings (Fig. 5b) with an arbitrary location, at least 6 hydrants are needed, and placing the hydrants in the intersection zone allow to use 2-4 (depending on the status or number of storeys of the building) hydrants.

To determine the status, which also affects the number of hydrants located in the intersection zones, the following rules must be considered:

a) regulatory requirements related to the height of the building increase its status naturally and are given in the paper [6];

b) the status can be assigned to each building taking into account the survey of experts, which can contain the concept of fire resistance, and taking into account the social orientation, and the belonging of the building to a certain type of structure, the number of people in the building and other constantly changing modern requirements.

The higher the status of the building, the more hydrants need to be planned for placement in the intersection zones. The creation of a modern scale for the status of a building is a big urgent problem, which we do not consider in this paper.

Undoubtedly, the new strategy creates a fundamentally new approach to more costeffective routing of distribution lines, as well as optimization of the number of pumping stations and extinguishing hoses. We consider these problems in the next paragraph of the article.

\section{Optimization of Number of Pumping Stations and New Principles of Routing Distribution Lines}

This paragraph offers new graphical algorithms for planning, which is optimal in a certain sense, placement of pumps for external fire extinguishing and also offers 
mathematical models for optimization in the construction of various networks of external fire-fighting water supply for hydrants in a separate neighborhood where there are not large or special roads.

The considered mathematical models and methods for assessing the flow rate of the ring and gridiron distribution system of external fire-fighting water supply are known [7].

\subsection{Optimization of Ring Building using Traveling Salesman Problem for Various Metrics}

For the relevance of constructing optimal networks of shorter length, we present the standard formula given in [7]. The coefficient of hydraulic resistance takes into account the linear and local hydraulic losses in the section of the pipeline between the branches and in the branch and can be determined by the expression

$$
A=\frac{\rho}{2} \sum_{k=1}^{n} \frac{\xi_{k}(l)+\xi_{k}(m)}{F_{k}^{2}},
$$

where $n$ is a number of pipeline segments forming the considered section of the external fire-fighting water supply network; $\xi_{k}(l)$ is a coefficient of linear resistance on the $k$-th section of the pipeline; $\xi_{k}(m)$ is a sum of the coefficients of local resistances on the $k$-th section of the pipeline; $F_{k}^{2}$ is a flow area of the pipeline on the $k$-th section of the pipeline. Formula (8) shows the relevance of the problem on minimizing the total length of pipe sections.

The construction of the minimum length circular connection of all fire-fighting water supplies in the form of a closed graph without cycles, at each point of which one edge enters and leaves, is the classical traveling salesman problem [9] or the construction of the length-optimal Hamiltonian graph (Fig. 6). This problem can be solved by simple computer search, or using special well-known algorithms [9]. However, in practice, the problem is more complicated, since the size, shape and location of modern buildings do not allow modelling the optimization problem in the Euclidean distance (or simply in a straight line). In this case, the traveling salesman problem must be solved not in the Euclidean distance, but in the metric of the space $l_{1}^{n}$. A computer program for solving the problem must be written using this metric. In this program, distance can be calculated using formula (3). The position of the broken strip can be changed (Fig. 2). In the known scientific works, we did not find such a description of the construction of a ring joint, as well as optimization of its length using the modified traveling salesman problem.

Note that in the modern urban planning of subdistricts, there are several main types of building: line, regular, sporadic, cluster housing, etc. Therefore, for each type of building it is necessary to plan an individual scheme of water supply to external water supply hydrants. Therefore, according to the authors, the circular structure of the water supply is most suitable for cluster housing and line building of the subdistrict (Figs. 7, 8).

\subsection{Construction of Gridiron Distribution System of a Special Type}

Let us assume that construction of a pumping station of a new type is allowed. This is a special-action station, which, upon a signal, can selectively deliver fire-fighting water supply to hydrants that are located in the close proximity of the fire impacted area, and the station does not send water to other points, thereby saving all possible costs. Where 


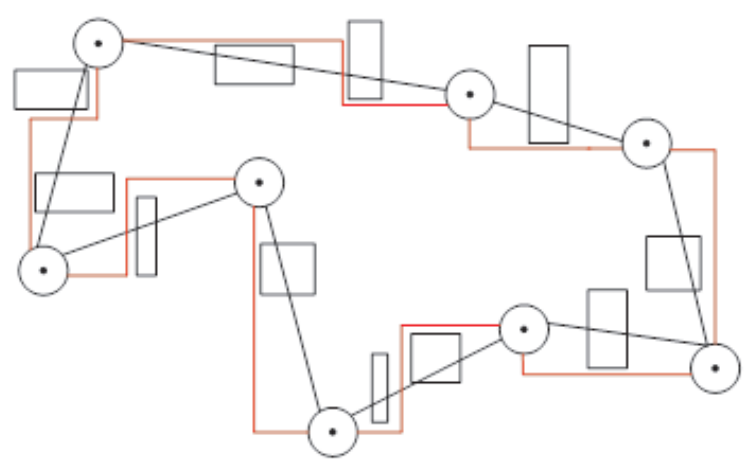

Fig. 6. Example of a ring construction scheme

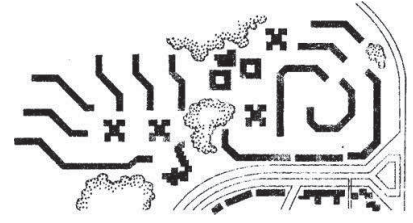

Fig. 7. Cluster housing

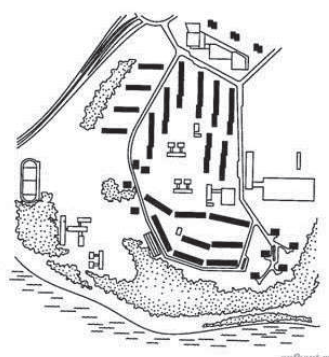

Fig. 8. Line building

should this station be located so that the total length of pipe sections is the smallest (Fig. 9)? The problem on finding the coordinates of such a station is the problem on determining the coordinates of the Fermat-Toricelli-Steiner point $[6,10,11]$.

Let us formulate the problem in general form: in the coordinate Banach space, it is necessary to determine the coordinates of the point $M$, the sum of distances from which to the fixed $n$ points $\left(A_{1}, A_{2}, \ldots, A_{n}\right)$ is minimal in the metric of this space.

The papers $[10,11]$ obtain computer algorithms and present programs for a computer (approximate) solution of this problem using the Java2 and $C^{++}$languages, for any number of points, and with any given accuracy. In the program, accuracy can be set based on practical feasibility.

Can the location of the pumping station, guaranteed by the optimization, be different if the measurements take place in different metrics?

Whether the location of the pumping station guaranteed by optimization can be different - if the measurements occur in different metrics. This is shown in Fig. 9. A circle and a shaded rectangle mark the optimal location of the pumping station in the case of a straight line measurement and in the case of the metric of the space $l_{1}$, respectively. 


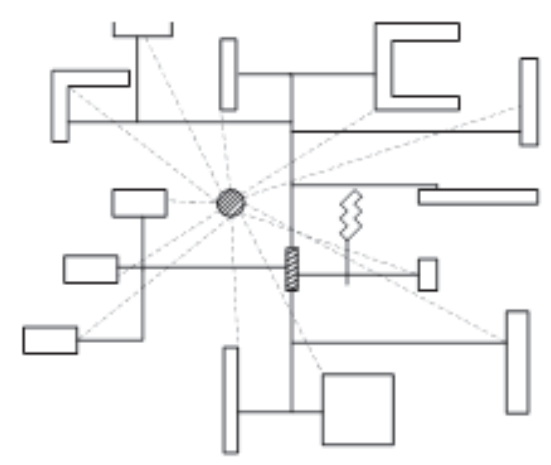

Fig. 9. An example of construction of a gridiron distribution system

In order to explain this phenomenon, we note that the work [11] proves that even if the "consumer points" are located on a circle, the Fermat-Steinberg points do not coincide, they have different coordinates, when measured in different metrics.

\subsection{Computer Graphics}

The Fermat-Steiner point is constructed using iterative programs, which reduce the search space at each step and calculate the values of the target functions of the form

$$
F_{l_{1}}(x, y)=\sum_{k=1}^{n}\left|x-x_{k}\right|+\left|y-y_{k}\right|, F_{l_{2}}(x, y)=\sum_{k=1}^{n} \sqrt{\left(x-x_{k}\right)^{2}+\left(y-y_{k}\right)^{2}} .
$$

The geometric interpretation of finding the Fermat-Steiner points is shown in Fig. 10 for the case of the space $l_{1}$ (right) and the space $l_{2}$ (left).

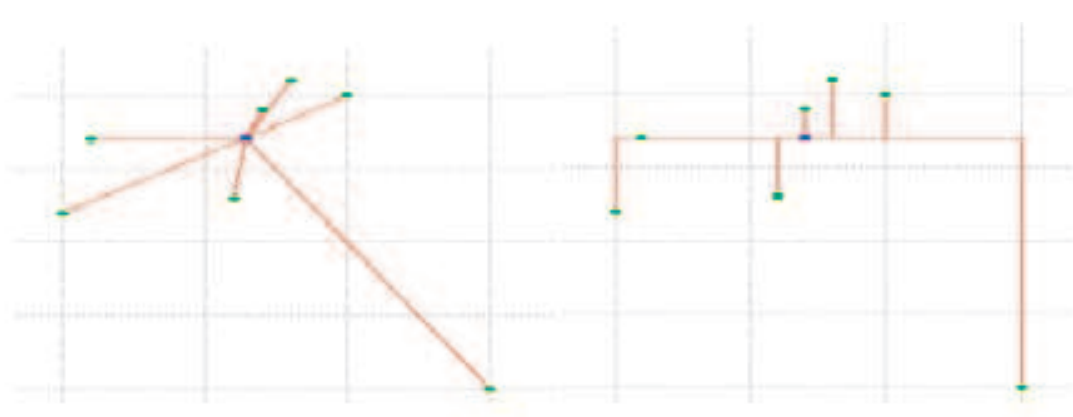

Fig. 10. Determination of the Fermat-Steiner point and tracing in Euclidean distance and in the metric of the space $l_{1}$

For the problem with pipe laying, in the case where the complexity depends on the direction of the laying, we can consider the optimization target function with complexity coefficients (weights) of the form

$$
F_{s}(x, y)=\sum_{k=1}^{n} \mu_{k} \sqrt{\left(x-x_{k}\right)^{2}+\left(y-y_{k}\right)^{2}}
$$


The geometric solution of application (9) is shown in Fig. 11. The complexity vector $\bar{\mu}=(1 ; 1,5 ; 1,2 ; 2 ; 2 ; 1,4)$ is set in the program. The appearance of such coefficients is known, for example, the tortuosity of the fire hose is 1,2 .

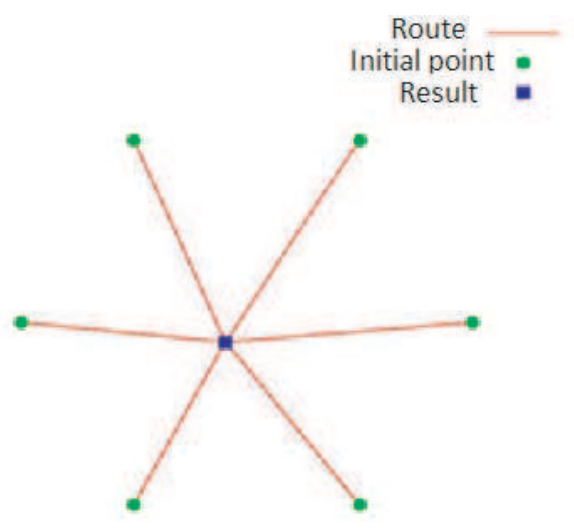

Fig. 11. The geometric solution of application (9)

Note that, according to the authors, the gridiron distribution system of the water supply is most suitable for the perimeter and free development of the subdistrict (Fig. 12).

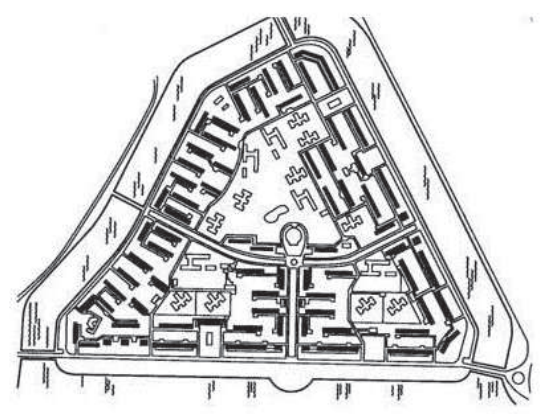

Fig. 12. Perimeter building

When rendering Figs. 10-11, we used the developed environment Vusual Studio 2019 with use of Windows Forms. The programming language is $C^{++}$, and we used the Microsoft .NET Framework. Library-ILNumerics (the library of mathematical classes for implementing numerical algorithms on the NET platform).

\section{Conclusion}

The main point noted in the paper is that the modern layout of buildings in modern neighborhoods and the size of buildings make it impossible to apply existing regulatory requirements on a radial basis for the design of outdoor fire water supply. Placement of fire-fighting water supply occurs without approval of the building layout. Measuring the distance in a straight line significantly complicates practical actions in the organization of fire-fighting. The regulatory requirements do not specify optimization problems. 
In Section 1, we obtain the geometric models that allow to place compactly a firefighting water supply group that can serve several buildings at the same time. Such a layout makes it possible to reduce the number of necessary fire-fighting water supplies by more than three and algorithms of their placement and the required number. The new approach, based on the planning of certain zones, takes into account the shape and number of floors of buildings. The construction of zones of influence occurs in the metric of space, which takes into account the mainly rectangular shape of buildings.

In Subsection 2.1, when organizing a ring network of external fire-fighting water supply, the total length of pipes is optimized. In this case, not a separate fire-fighting water supply is connected into a ring, but the zones of their placement, described in Section 1. Such an organization also allows to optimize the number of fire-fighting water supplies required in the area. Moreover, these zones can be arranged in any order. We arrive at the optimization problem to find a chain with the minimum total length of all pipes that make up this chain. Its solution is used to construct a chain of minimum length.

In Subsection 2.2, various special gridiron distribution system of external fire-fighting water supply of zonal action are designed. In these systems it is possible to selectively supply water to the exact area where the fire occurred. Based on the development of modern methods and methods of information transmission, we substantiate the advantages of these networks. When designing these networks, depending on the complexity of pipe laying, geometry of placement and the size and shape of buildings, we propose to use different metrics for measuring lengths on a plane. When constructing, we use the problem on finding the coordinates of the Fermat-Steiner point for various metrics. This problem is solved by computer programs for the numerical determination of coordinates with iterative verification of the target function value. The type of function depends on the method (metric) of distance measurement.

\section{References}

1. Gurov A. V., Gridnev E. Yu. [To the Question of Creating a Fire-Fighting Water Supply]. [Bulletin of Voronezh Institute of state fire service of EMERCOM of Russia], 2012, no. 1, pp. 49-51. (in Russian)

2. [Hydraulics and Fire Water Supply]. Ed. by E.D. Maltsev. Moscow, 1976. (in Russian)

3. Abrosimov Yu. G. [Hydraulics and Fire Water Supply]. Moscow, Academy of GPS EMERCOM of Russia Publ., 2003. (in Russian)

4. Ivanov E. N. [Fire Water Supply]. Moscow, Stroizdat Publ., 1986. (in Russian)

5. Polyakov D. V. 100 Questions and Answers on the Design of Automatic WaterExtinguishing Installation. Part no. 20 (96-100)]. Moscow, Academy of emergency situations, 2017. (in Russian)

6. Cherepanov E. A., Rodin V. A., Kalach A. V., Akulov A. Yu. Algorithms for Optimum Location of Outdoor Fire Water Hydrants. Proceedings of Voronezh Institute of the Russian Federal Penitentionary Service, 2019, no. 4, pp. 124-131. (in Russian) 
7. Pivovarov N. Yu., Tarantsev A. A. Modeling Water Loss of Ring Networks External Fire Water Supply. Fire and Explosion Safety, 2014. vol. 23, no. 12, pp. 69-75. (in Russian)

8. Menshikh V. V., Kalkov D. Yu. [Optimization of Response Groups for Protection Objects]. Fire Safety: Problems and Prospects, 2015, vol. 2, no. 1(6), pp. 381-384. (in Russian)

9. Ulanov E. A., Uteshev A. Yu. [Analytical Solution of the Generalized Fermat Torricelli - Steiner Problem]. Management Processes and Sustainability: Proceedings of the 42nd International Scientific Conference of Postgraduates and Students. St. Petersburg, Publishing house of St. Petersburg State University, 2011, pp. 201-206. (in Russian)

10. Rodin V. A., Rodina E. V. [Fermat - Steiner Points in Banach Spaces with Different Metrics]. Management Systems and Information Technology, 2016, no. 1(63), pp. 17 20. (in Russian)

11. Bondarenko E. S., Grechanyy S. A., Rodin V. A. Numerical Modeling of Problems of the Optimal Location of a Serving Object using Analogues of the Fermat - Steiner Points. Vestnik of Voronezh Institute of the Ministry of the Interior of Russia, 2017, no. 2, pp. 154-161. (in Russian)

12. Grishanov M. V., Rodin V. A. [Numerical Modeling of Optimal Placement Problems using Analogs of Fermat -Steiner Points]. Physical and Mathematical Modeling of Systems: Materials of the XVIII International Seminar. Voronezh, Publishing house of Voronezh State Technical University, 2018, pp. 37-39. (in Russian)

Andrey V. Kalach, DSc (Him), Professor, Head of the Department of Information Security and Protection of Information Constituting the Public Service, Voronezh Institute of Russian Federal Penitentiary Service (Voronezh, Russian Federation), AVKalach@gmail.ru.

Vladimir A. Rodin, DSc (Math), Professor, Department of Mathematics and Systems Modeling, Voronezh Institute of the Ministry of Interior of Russia (Voronezh, Russian Federation),rodin_v@mail.ru.

Sergey V. Sinegubov, PhD (Techn), Associate Professor, Department of Mathematics and Systems Modeling, Voronezh Institute of the Ministry of Internal Affairs of Russia, Voronezh, Russian Federation, sinusdvm@mail.ru.

Received November 20, 2020. 


\title{
ОПТИМИЗАЦИЯ СИСТЕМ ПРОТИВОПОЖАРНОГО ВОДОСНАБЖЕНИЯ С ПОМОЩЬЮ ПРОСТРАНСТВЕННЫХ МЕТРИК
}

\author{
А. В. Калач, В. А. Родин, С.В. Синегубов
}

\begin{abstract}
Современная тенденция строительства новых городских районов предполагает комплексное предварительное планирование всех систем и сетей энергоснабжения, водоснабжения, водоотводных комплексов, прокладки сетей связи и других коммуникационных сетей объектов строительства согласовывать с планировкой размещения жилых домов. В работе, с помощью различных метрик, измеряющих расстояние, оптимизируется численность и вид распределения гидрантов наружного противопожарного водоснабжения и насосных станций. Рассмотрена оптимизация зависимости вида сетей водоснабжения гидрантов от насосных станций, учитывающая реальные практические задачи по обеспечению противопожарного водоснабжения с учетом размеров, расположений и формы современных зданий. Проведенный анализ карт и нормативов выявил, что понятие расстояние подразумевает только расстояние по прямой, что совершенно не соответствует как современной планировке застройки микрорайонов, так и существенно затрудняет практическую возможность работы пожарных. В первой части работы приводится математическая модель, оптимизирующая как численность, так и расположение множества гидрантов, полностью обслуживающих заданный район застройки. Алгоритм оптимизации использует метрики отличные от Евклидовой. При этом предполагается, что разработанные модели применимы для различных видов застройки микрорайонов (строчной, регулярной, групповой, свободной и др.). Во второй части работы с помощью компьютерного определения координат точки Торричелли - Штейнера, построенной для произвольного множества точек-потребителей и различных пространственных метрик, оптимизируется численность размещения насосных станций и вид сети трубопроводов связывающих пожарные гидранты и насосные станции.

Ключевые слова: алгоритм расположения; пожарный гидрант; противопожарное водоснабжение; моделирование; пространственные метрики; точки Торричелли Штейнера.
\end{abstract}

\section{Литература}

1. Гуров, А. В. K вопросу о создании противопожарного водоснабжения / А. В. Гуров, Е. Ю. Гриднев // Вестник Воронежского института ГПС МЧС России. 2012. - № 1(2). - C. 49-51.

2. Гидравлика и пожарное водоснабжение / Под ред. Е. Д. Мальцева. - М., 1976.

3. Абросимов, Ю. Г. Гидравлика и противопожарное водоснабжение / Ю. Г. Абросимов и др. - М.: Академия ГПС МЧС России, 2003.

4. Иванов, Е. Н. Противопожарное водоснабжение / Е. Н. Иванов. - М.: Стройиздат, 1986.

5. Поляков, Д. В. 100 вопросов и ответов по проектированию АУВП. Часть № 20 (96-100) / Д. В.Поляков. - М.: Академия МЧС, 2017. 
6. Черепанов, Е. А. Алгоритмы оптимального расположения гидрантов наружного противопожарного водоснабжения / Е. А. Черепанов, В. А. Родин, А. В. Калач, А. Ю. Акулов // Вестник Воронежского института ФСИН России. - 2019. - № 4. C. $124-131$.

7. Пивоваров, Н. Ю. Моделирование водоотдачи кольцевых сетей наружного противопожарного водопровода / Н. Ю. Пивоваров, А .А. Таранцев // Пожаровзрывобезопасность. - 2014. - Т. 23, № 12. - С. 69-75.

8. Меньших, В. В. Оптимизация групп реагирования по объектам защиты / В. В. Меньших, Д. Ю. Калков // Пожарная безопасность: проблемы и перспективы. - 2015. - Т. 2, № 1(6). - С. 381-384.

9. Уланов, Е. А. Аналитическое решение обобщенной задачи Ферма - Торричелли Штейнера / Е. А. Уланов, А. Ю. Утешев // Процессы управления и устойчивость: Труды 42-й международной научной конференции аспирантов и студентов // Под ред. А. С. Ерчмина, Н. В. Смирнова. - СПб.: Издат. дом С.-Петерб. гос. ун-та, 2011. - C. 201-206.

10. Родин, В. А. О точках Ферма - Штейнера в банаховых пространствах с различной метрикой / В. А. Родин, Е. В. Родина // Системы управления и информационные технологии. - 2016. - № 1(63). - С. 17-20.

11. Бондаренко, Е. С. Численное моделирование задач оптимального размещения обслуживающего объекта с использованием аналогов точек Ферма - Штейнера / Е. С. Бондаренко, С. А. Гречаный, В. А. Родин // Вестник ВИ МВД России. 2017. - № 2. - C. 154-161.

12. Гришанов, М. В. Численное моделирование задач оптимального размещения с использованием аналогов точек Ферма - Штейнера / М. В. Гришанов, В. А. Родин // Физико-математическое моделирование систем: материалы XVIII Международного семинара. - Воронеж: Воронежский гос. технический ун-т, 2017. - C. 37-39.

Калач Андрей Владимирович, доктор химических наук, профессор, начальник кафедры безопасности информачии и защиты сведений, составляющих государственную службу, Воронежский институт ФСИН России (г. Воронеж, Российская Федераuия),avkalach@gmail.ru.)

Родин Владимир Александрович, доктор физико-математических наук, профессор, кафедра математики и моделирования систем, Воронежсккий институт МВД России (г. Воронеж, Российская Федерачия), rodin_v@таil.ru.

Синегубов Сергей Владимирович, кандидат технических наук, дочент, кафедра математики и моделирования систем, Воронежский институт МВД России (2. Воронеж, Российская Федераиия), sinusdvm@mail.ru.

Поступила в редакцию 20 ноября 2020 г. 